\title{
Toxoplasma gondii infection in slaughtered domestic ruminants in Northwest Ethiopia: seropositivity, bioassay and virulence assessment
}

\section{Moges Maru}

University of Gondar

Debasu Damtie

University of Gondar

Ambaye Kenubih

University of Gondar

Abiy Maru

University of Gondar

Biyansa Adugna

Samara University

Shimelis Dagnachew

University of Gondar

Zewdu Seyoum Tarekegn ( $\nabla$ zewdu.seyoum@uog.edu.et)

University of Gondar https://orcid.org/0000-0002-5291-2795

\section{Research Article}

Keywords: Bioassay, Ruminants, Seropositivity, Toxoplasma gondii

Posted Date: June 22nd, 2021

DOl: https://doi.org/10.21203/rs.3.rs-640242/v1

License: (9) (i) This work is licensed under a Creative Commons Attribution 4.0 International License.

Read Full License 


\section{Abstract}

This study investigated the seropositivity, isolation and virulence of Toxoplasma gondii in slaughtered domestic ruminants in Gondar city, Northwest Ethiopia. Three hundred thirty-five blood samples (135 sheep, 50 goats and 150 cattle) were collected from slaughterhouses. Antibodies against T. gondii were assayed using a commercial Toxo-Latex agglutination test. Tissue digestion was also conducted on 39 heart muscles of seropositive animals using the pepsin enzyme. The isolation of viable $T$. gondii from seropositive ruminants was also performed in white albino mice. The overall seroprevalence of $T$. gondii infection was found to be $55.8 \%$. The species-wise prevalence of $T$. gondii seropositivity in cattle, goats and sheep was $59.3 \%, 58 \%$, and $51.1 \%$, respectively. From observed risk factors, sex $(p<0.033)$ and age of the sheep $(p<0.006)$ showed a significant association with $T$. gondii seropositivity. Similarly, in cattle, age $(p<0.005)$ and breed $(p<0.012)$ showed a statistically significant association with seropositivity of anti- . gondii antibodies. In bioassayed mice, the overall viable T. gondii isolates were $38.5 \%$ and most of these isolates (87.18\%) were avirulent. In conclusion, the high prevalence of $T$. gondii antibody and a high proportion of viable $T$. gondii observed in this study indicated the prevalent nature of the parasite and its zoonotic importance in the study areas where slaughtered domestic ruminants serve as an important human protein source. Education of the public about routes of $T$. gondii transmission and control methods is imperative to prevent $T$. gondii transmission.

\section{Introduction}

Toxoplasma gondii is an obligate intracellular parasite, which can infect all warm-blooded vertebrates including humans, mammals and birds (Schlüter et al., 2014). It infects up to $30 \%$ of the human population in the globe (Dubey, 2010). Humans can acquire the infections by ingesting sporulated oocystcontaminated food, vegetables and water; by consuming raw or undercooked meat containing viable tissue cysts of this parasite from infected food animals, and congenitally from an infected mother to the foetus (Dubey, 2010; Schlüter et al., 2014). Felids play a key role in the epidemiology of $T$. gondii infection in animals and humans as final hosts by shedding millions of environmentally resistant viable oocysts through their faeces (Dubey, 2010; Schlüter et al., 2014). Feline become infected through the consumption of tissues containing viable cysts from intermediate hosts (Dubey, 2010; Robert-Gangneux and Darde, 2012) or, less effectively, through the ingestion of sporulated oocysts (Dubey 2006; Saadatnia and Golkar, 2012; Cornelissen et al., 2014; Shapirro et al., 2019; Attias et al., 2020).

Ruminants are considered important in the epidemiology of T. gondii infection worldwide (Tenter, 2009; Dubey, 2010). The ingestion of infected meat from food animals serves as a direct source of infection for humans and felines. In most areas of the world, Toxoplasma infection is prevalent in meat-producing animals (Tenter, 2009; Tonouhewa et al., 2017; Stelzer et al., 2019) and pose a risk to public health (Garcia-Bocanegra et al., 2013; Gharbi et al., 2013; Gazzonis et al., 2020) because humans can acquire the pathogen from infected food animals through raw or undercooked meat and milk consumption (Yang et al., 2012; Al-Kappany et al., 2018). Infection of pregnant women results either in abortion or congenital 
infection of the foetus. The congenital infection of foetuses results in hydrocephalus, intracranial calcification and retinochoroiditis (Schlüter et al., 2014; Tonouhewa et al., 2017; Hosseini et al., 2019).

Several serological surveys have indicated $T$. gondii infection is prevalent in Ethiopian sheep, goats and cattle (Negash et al., 2004; Teshale et al., 2007; Gebremedhin et al., 2013; Zewdu et al., 2013; Tegegne et al., 2016; Tilahun et al., 2018; Esubalew et al., 2020). However, little is known about the viability and virulence of $T$. gondii isolates detected in the meat of such seropositive animals. Therefore, this study was conducted: 1 ) to estimate the prevalence of $T$. gondii antibodies in sheep, goat and cattle destined for slaughter in Gondar city, Northwest Ethiopia; 2) to assess the viability and virulence of $T$. gondii isolate using mice bioassay.

\section{Materials And Methods}

\subsection{Study Design and Sampling Technique}

A cross-sectional study design was employed to collect blood and tissue samples from slaughtered domestic ruminants at Gondar ELFORA abattoir and four local slaughterhouses in Gondar city. A laboratory-based experimental follow up in bioassayed mice was also performed from November 2018 to June 2019. A total of 335 animals (135 sheep, 50 goats and 150 cattle) were sampled for the study. The age of the animals was determined by observing the erupted permanent incisors (Taylor, 1984; Awgichew \& Abegaz, 2008). The approximate age of the animals was categorised and recorded as young, adult and old. Sheep and goats $\leq 1$ year were considered as young, while those over one year were considered an adult. In the case of cattle, those with $\geq 7$ years were considered as old, while those having four to seven years old were considered adults.

\subsection{Sample collection and transportation}

A total of 335 blood samples, each about 5-10 ml whole blood, were collected using plain sterile tubes during exsanguination or intracardially at the slaughter line. Out of the total 335 blood samples, 200 had matched heart tissue samples ( 75 from cattle, 75 from sheep and 50 from goats) for microscopic examination and bioassay in mice. Each collected tissue sample weighed about 50-60 gram. The samples were labelled and transported with a cold box to the Veterinary Parasitology laboratory, College of Veterinary Medicine and Animal Sciences, University of Gondar.

\subsection{Serological assay}

The blood samples were allowed to clot in a slant position for a few minutes and centrifuged at $4000 \mathrm{rpm}$ for $5 \mathrm{~min}$ to separate the sera. Subsequently, sera were decanted into $1.5 \mathrm{ml}$ Eppendorf tubes.

Toxoplasma gondii antibodies were assayed in the collected serum samples using the Toxo-latex slide agglutination test (SPINREACT, S.A/S.A.U, GIRONA, SPAIN) following the previous reports (Ibrahim et al., 2014; Tegegne et al., 2016) and manufacturer's recommendations. Agglutinates were detected using the naked eye and stereomicroscope. The presence of agglutination was considered as positive at a titre of $\geq 1: 2$ and indicates an antibody concentration equal to or greater than $4 \mathrm{IU} / \mathrm{ml}$. The laboratory 
procedures were performed at the University of Gondar, College of Veterinary Medicine and Animal Sciences, Veterinary Parasitology Laboratory.

\subsection{Tissue digestion and Bioassay in mice}

Tissue samples from seropositive animals were digested as described by Dubey (1998). Briefly, tissue samples weighing 50 grams were minced and digested in a pepsin acid solution $(\mathrm{pH} 1.1-1.2)$ at $37^{\circ} \mathrm{C}$ for $1 \mathrm{hr}$. After filtration, neutralisation was executed one time with $1.2 \%$ sodium bicarbonate solution $(\mathrm{pH}=$ 8.3) and then centrifugation was performed. Thus, the sediment was diluted in 5-10 ml of antibiotic

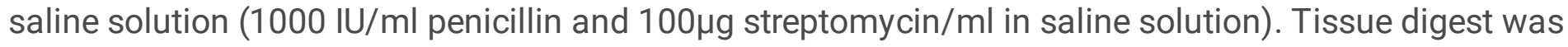
examined microscopically at 10x and 40x magnification power. Accordingly, liberated bradyzoites and/or tissue cysts of T. gondii were examined under a microscope from the tissue digests. Then, 39 microscopically positive digested tissue samples were inoculated subcutaneously into mice to assess the viability and virulence of the detected cysts. 5-6 weeks of aged female white albino mice weighing 2025-gram were used for the experiment. Each microscopically positive digested tissue sample was inoculated into 5 mice ( $1 \mathrm{ml}$ suspension per mouse). Approximately $5 \mathrm{ml}$ aliquots from the suspension were leftover and stored at $+4^{\circ} \mathrm{C}$ until it was inoculated in the same mice next day (Beltrame et al., 2012). After inoculation, mice were followed for 49 days for the occurrence of clinical signs and death. During the follow-up, mice were offered pelleted feed and drinking water ad libitum. All survivors were then euthanised on the 49th -day post-inoculation through cervical dislocation after anaesthetising with diethyl ether and blood was collected through cardiac puncture. The blood was allowed to clot for about 3 to 4 hours and then the top part was pipetted and centrifuged at 4000 RPM for 4 minutes, as the serum was not completely clear. The serum was harvested using a disposable pipette into an Eppendorf tube and tested on the same day by LAT. Thus, the sera were examined for T. gondii antibodies using the LAT.

Further, the brain of the mouse was homogenised in $1 \mathrm{ml}$ phosphate-buffered saline $(\mathrm{pH}=7.2)$ using a mortar and pestle to detect the cysts microscopically. The number of cysts in the brain of each mouse was determined by converting the sum of cysts in $30 \mu \mathrm{l}$ to the whole of the brain homogenates (Goodwin et al., 2008; Fritz et al., 2012). The bioassay was considered as positive if at least one T. gondii cyst is detected in any inoculated mouse or if at least one of the mice sera reacts positively by the LAT (Dubey et al., 1995). The virulence of the parasite was classified according to Pena et al. (2008) based on mice mortality rate within four weeks of infection (without prior information on infecting dose). Then, we categorized isolates into three groups: virulent (if there were $100 \%$ death of mice within four weeks), intermediate virulent (30\% to less than $100 \%$ death within four weeks), and non-virulent (<30\% death within four weeks).

\subsection{Data Analysis}

The data obtained were stored in a Microsoft Excel spreadsheet (2010) and analysed using SPSS version 20 (SPSS Inc., Chicago, IL, USA). The data were summarized using descriptive statistics. The association of seropositivity for T. gondii and, age (young, adult and old), sex (male and female), breed (local and 
cross) and species (cattle, sheep and goat) was tested using the chi-square test. The $95 \%$ confidence level was used and statistical analyses were considered significant at $P<0.05$.

\subsection{Ethical clearance}

The animal welfare committee of the College of Veterinary Medicine and Animal Sciences, University of Gondar approved the project (Ref. No. O/V/P/RCS/05/1237/2018).

\section{Results}

\subsection{Prevalence of Toxoplasma gondii antibodies}

The overall prevalence of $T$. gondii antibodies in slaughtered domestic ruminants was found $55.8 \%$ (95\% Cl: 50.1-61.2). At species level, it was relatively higher in cattle $59.3 \%$ (95\% Cl: $51.4-67.3)$ followed by goats 58\% (95\% Cl: $44.0-72.0)$ and sheep 51.1\% (95\% Cl: 43-60). Toxoplasma gondii antibodies prevalence was significantly varied with sex $(p<0.033)$ and age of sheep $(p<0.006)$. Similarly, in cattle, age $(p<0.005)$ and breed $(p<0.012)$ showed significant association with the prevalence of $T$. gondii antibodies (Table 1). However, in goats, no variation was observed either with sex or age groups.

Table 1: Association between hosts related factors and T. gondii antibodies prevalence

\subsection{Bioassay in mice}

Thirty-nine positive tissue samples containing T. gondii tissue cysts and/or liberated bradyzoites (Fig. 1) (14 from cattle, 16 from sheep and 9 from goats) were bioassayed in 194 mice. The total viable $T$. gondii isolated from the three species of animals was 38.5\% (15/39) (Table 4). At the species level, viable $T$. gondii was isolated from $50 \%$ (8/16) of sheep, $44.4 \%$ (4/9) of goats and $21.43 \%$ (3/14) of cattle.

However, a sample can be both cyst positive and seropositive, and cyst positive and seronegative or vice versa. The summary of viability data as indicated by serological and cyst positivity in inoculated mice is presented in Table 2 and detailed data for each tested isolate is provided in Table 3.

Figure 1: T. gondii tissue cysts (I) and liberated bradyzoites (II).

Table 2: Summary serological and cyst positivity of inoculated mice by T. gondii isolate from slaughtered domestic ruminants

Table 3: Detailed viability data for each bioassayed isolate as indicated by serological and cyst positivity in the inoculated mice.

The overall seropositivity of $T$. gondii in experimentally infected and surviving mice from all animal species was found to be $16.4 \%(27 / 165)$. The seropositivity of $T$. gondii infection in experimentally infected mice using inoculum from sheep, goat and cattle was $18.2 \%(12 / 66), 16.7 \%(6 / 36)$ and $14.3 \%$ (9/63), respectively. A total of 21 experimentally infected mice were found to harbour $T$. gondii tissue cysts. Some of the tissue cysts detected in inoculated mice are presented in Fig. 2. 
Figure 2: Tissue cysts of $\mathrm{T}$. gondii isolated from the brain of mice: from sheep sample inoculum [A= unstained 40x], goat sample inoculum [B = unstained; $C=$ impression smear 100x], and cattle [D impression 100x smear]. Note the thin cyst wall (arrow) enclosing bradyzoites.

The overall mean cyst detected and enumerated from experimentally infected mice was $162.57 \pm 34.840$ (mean $\pm \mathrm{SE}=$ ) cysts per brain of mice. Overall, higher mean cyst counts in the brains of mice inoculated with heart homogenates from goats were quantified compared to those enumerated in the bioassay performed on the sheep and cattle samples (Table 3).

Table 4: Mean cyst counts in the brains of mice inoculated with heart homogenates of slaughtered animals.

\subsection{Clinical signs in mice}

During the follow-up, most inoculated mice were asymptomatic. However, 29 mice ( 7 from cattle, 13 from sheep and 9 from goats) died before the 49th days. More specifically, 9 mice ( 5 from sheep and 4 from goat's inoculum) died on 3rd and 4th days after inoculation while 20 mice (8 from sheep, 7 from cattle and 5 from goats' inoculum) died after the 4th day's postinoculation (pi). The clinical symptoms observed in symptomatic mice were arched back, leg paralysis, tachypnoea, inappetence, rough hair coat and dullness.

\subsection{Virulence of $T$. gondii isolates}

Two isolates from the sheep with identification sp15 killed one mouse on day 8-pi (Table 2). Most of the recovered isolates $(87.18 \%)$ in this study were nonvirulent to the mice. One highly virulent isolate (sp67) and four intermediate virulent isolates, namely, sp26, B65, Gt6, and Gt28 were suggested (Table 2).

\section{Discussion}

\subsection{Prevalence of $T$. gondii antibodies in slaughtered domestic ruminants}

The overall prevalence of $T$. gondii among slaughtered domestic ruminants was found to be $55.8 \%$. This finding is higher than the reported prevalence of $22.2 \%$ from Eastern Ethiopia (Tilahun et al., 2018) and 37\% from Tunisia (Lahmar et al., 2015). In this study, a significant association was observed with $T$. gondii seropositivity and, age and sex of sheep. It agrees with previous reports across the globe (Yibeltal, 2008; Ramzan et al., 2009; Gebremedhin et al., 2013; 2014). It could be attributed to the high chance of exposure to the source of infection as age increases and suggests that most sheep acquire the infection postnatal (Andrade et al., 2013; Opsteegh et al., 2016). In cattle, older and cross-breed animals also showed significantly higher $T$. gondii seropositivity than adult and local breed cattle. Older animals as they lived longer might be more likely to be exposed to the infectious agent from different sources (Jittapalapong et al., 2005; Teshale et al., 2007; Ramzan et al., 2009; Andrade et al., 2013; Opsteegh et al., 2016; Amdouni et al., 2017). 


\subsection{Bioassay in mice}

The overall viable $T$. gondii isolation rate of $38.5 \%$ in the current study shows a lower percentage compared to the report of (Berhanu, 2015) who reported $67.6 \%$. However, this study indicates a higher percentage value than the report of (Elfadaly et al., 2017) who reported 8.57\% (12/140) in domestic ruminants (sheep, goats and cow) from Egypt. The isolation rate of viable $T$. gondii in this study in sheep (50\%) $(95 \% \mathrm{Cl}: 25-75)$ is comparable with the report of isolation rates of $57.45 \%$ from central Ethiopia (Gebremedhin et al., 2014) and with findings from France with the isolation rates of 26.7\% (Dumètre et al., 2006) and from Egypt with isolation rate of $32 \%$ (Younis et al., 2015). In contrast, the current result is lower than the report from the USA with the isolation rates of $77.9 \%$ (Ragozo et al., 2008) and higher than the report from Brazil 19.5\% (Ragozo et al., 2009) from MAT seropositive sheep. In goat, isolation rates of viable $T$. gondii (44.4\%) in the current study are in parallel with the reported isolation rate of $45.45 \%$ in central Ethiopia (Gebremedhin et al., 2014) and 46.15\% in Sao Paolo, Brazil (Ragozo et al., 2009).

However, it disagrees with records of Berhanu (2015) 75\% from Eastern Ethiopia, (Dubey et al., 2011) 26\% from Brazil and (Opsteegh et al., 2011) 62.8\% from the USA. The differences between these reports may be due to the density of $T$. gondii in tissues of sheep and goats, the type of tissue sampled and the strain or genotype of T. gondii. Toxoplasma gondii localised more often in the muscles than in the brain of sheep and goats (Dubey, 2010).

Attempts to isolate viable $T$. gondii from cattle tissues have been extremely rare. Only a few successful tissue cyst recoveries have been reported (Scarpelli et al., 2009). This study in cattle on the isolation rate of viable T. gondii (21.43\%) via bioassay in mice is comparable with the report of Opsteegh et al. (2016) who demonstrated $3.3 \%$ of viable T. gondii from selected European countries. However, the finding of the current study is higher than the reported isolation rate of $0 \%$ from Ethiopia in cattle (Berhanu, 2015), $0 \%$ from Egypt in cow (Elfadaly et al., 2017) through bioassay in mice and lower than the reported isolation rate of $100 \%(18 / 18)$ in experimentally infected cattle confirmed via bioassay in mice (Deksne \& Kirjušina, 2013). The differences between this report and aforesaid reports may be due to the density of T. gondii in tissues of cattle, the type of tissue sampled, the digestion method used and the strain or genotype of $T$. gondii (Dubey, 2010).

The overall prevalence of $T$. gondii antibodies in experimentally infected and surviving mice, from all animal species, was $16.4 \%(27 / 165)$. This finding is in agreement with the report of Gebremedhin et al. (2015) who reported $16.8 \%$ seroprevalence in experimentally infected mice with heart homogenates of the pig. However, it is lower than the report of Endrias et al. (2015) who reported 30.58\% seroprevalence. The overall prevalence of $T$. gondii tissue cysts was detected in the brains of experimentally infected mice was $12.7 \%$. This finding lower than the reported cyst percentage of $17.6 \%$ by Gebremedhin et al., (2015) and the reported cyst percentage of $28.82 \%$ by Endrias et al., (2015). The mean cyst count per brain of mice in this study was 162.57 (mean $\pm S E=162.57 \pm 34.840$ ). This finding is comparable with the mean tissue cyst count of 157.2 from central Ethiopia (Gebremedhin et al., 2015). However, it is lower than 277.97 mean cyst count per brain from central Ethiopia (Gebremedhin et al., 2014), tissue cyst counts ranging from 297 to 1380 by Brown et al. (1995) and the mean number of tissue cysts of 600 by 
Goodwin et al. (2008), but higher than the previous report by (Tesfamariam 2013) in free-range chicken from Ada'a Liben, Central Ethiopia with the mean tissue cyst count of 57.4 per brain of mice. Toxoplasma gondii cyst burden in mice is only unassociated with inoculum dose and route, but also by the inoculated parasite strain (Waree et al., 2007) or by the genotype of mice (Brown et al., 1995; Waree et al., 2007). Besides, the number of live bradyzoites in the digested heart tissue of study animals inoculated into mice could contribute to the variation of the counted tissue cysts that are if inoculated bradyzoites are few, few of them reach the brain of mice, there will be fewer numbers of tissue cyst formed (Brown et al., 1995). Thus, microscopic counting of brain cysts in mice may indicate the infectious burden of $T$. gondii in ruminants (Bourguin et al., 1993).

\subsection{Clinical signs in mice}

During the follow-up, most inoculated mice were asymptomatic. However, 29 mice ( 7 from cattle, 13 from sheep and 9 from goats) died before the 49th days. The observed clinical picture in mice in this study was similar to that observed by Gebremedhin et al. (2014b; 2015), and (Kyan et al., 2012), who observed that clinical conditions varied across seropositive mice and include cowlick, depression and forced breathing and most of these symptomatic surviving mice recovered to a normal condition.

\subsection{Virulence of T. gondii isolates}

The majority (87.2\%) of the isolates recovered were avirulent to white Swiss Albino mice. This virulence assessment is in agreement with previous reports in Ethiopia (Gebremedhin et al., 2014; 2015). However, one isolate (sp67) from sheep inoculum was highly virulent killing all inoculated mice (5/5) on the 3rd and 4th day of post-infection. According to Pena et al., (2008), 100\% of death within four weeks of pi implies high virulence of $T$. gondii in mice. Besides, $80(4 / 5)$ and $40 \%(2 / 5)$ of mice were killed due to isolates from sample code (Gt 6) and (Gt 28), respectively from goat tissue inoculum within 4 weeks pi, and $40 \%(2 / 5)$ of mice from each sheep (sp26) and cattle (B65) sample inoculum died within four weeks postinfection. This may be an indication of intermediate virulence of T. gondii strains (Cook et al., 2000; Pena et al., 2008). Alternatively, T. gondii was also isolated from a homogenate of the intestine of the cow (Dubey 1992). According to Dubey et al., 2002; 2007b. T. gondii isolates differ markedly in their virulence to outbred mice. The avirulent strains were defined as no mortality at any dose, whereas a "low-dose survivability" phenotype was defined by survival time after injection of 100 parasites (Kyan et al., 2012). It has been suggested the $T$. gondii virulence in mice depends on several factors, including the stage of the parasite, route, dose, types of mice used, host and strain of the parasite (Dardé, 2004; Endrias et al., 2015). The observed clinical picture in mice in this study was similar to that observed by Gebremedhin et al. (2014b; 2015), and (Kyan et al., 2012), who observed that clinical conditions varied across seropositive mice and include cowlick, depression and forced breathing and most of these symptomatic surviving mice recovered to a normal condition.

In conclusion, this finding indicates a high overall seroprevalence of $T$. gondii infection in domestic ruminants slaughtered for human consumption. More importantly, the current result showed a high isolation rate of viable $T$. gondii from seropositive domestic ruminants slaughtered for human 
consumption. However, most of the recovered viable isolates were avirulent. Only one isolate from sheep inoculum was found virulent and four intermediate virulent isolates; one from sheep, one from cattle inoculum and two from goat inoculum. Therefore, the findings of high seropositivity, detection of viable $T$. gondii tissue cysts with some of them a variable degree of virulence coupled with currently increasing trends of beef, mutton and goat meat consumption in the study area signifies the public importance of the disease, particularly in vulnerable groups. Butchers and slaughterhouse workers that handle carcase and organs infected with $T$. gondii are also at risk of getting an infection with toxoplasmosis. Based on the findings of the study, the education of the public about routes of $T$. gondii transmission and control methods is imperative to prevent $T$. gondii transmission to humans. Further advanced diagnostic techniques should be used to identify the genotype and population structure of $T$. gondii strains.

\section{Declarations}

\section{Acknowledgements}

We would like to acknowledge the Office of Vice President for Research and Community

Service, the University of Gondar for its financial support.

Competing interests: The authors declare no competing interests.

\section{References}

1. Al-Kappany, Y.M., Abbas, I.E., Devleesschauwer, B., Dorny, P., Jennes, M., Cox, E. (2018).

Seroprevalence of anti-Toxoplasma gondii antibodies in Egyptian sheep and goats. BMC Vet. Res. 14 (1), 120. https://doi.org/10.1186/s12917-018-1440-1.

2. Amdouni, Y., Rjeibi, M. R., Rouatbi, M., Amairia, S., Awadi, S., \& Gharbi, M. (2017). Molecular detection of Toxoplasma gondii infection in slaughtered ruminants (sheep, goats and cattle) in Northwest Tunisia. Meat Science, 133, 180-184. https://doi.org/10.1016/j.meatsci.2017.07.004

3. Andrade, M. M., Carneiro, M., Medeiros, A. D., Andrade Neto, V., \& Vitor, R. W. (2013). Seroprevalence and risk factors associated with ovine toxoplasmosis in Northeast Brazil. Parasite (Paris, France), 20, 20. https://doi.org/10.1051/parasite/2013019

4. Attias, M., Teixeira, D. E., Benchimol, M., Vommaro, R. C., Crepaldi, P. H., \& De Souza, W. (2020). The life-cycle of Toxoplasma gondii reviewed using animations. Parasites \& Vectors, 13(1), 588. https://doi.org/10.1186/s13071-020-04445-z

5. Awgichew, K., \& Abegaz, S. (2008). Breeds of sheep and goats. Sheep and goat production handbook for Ethiopia: Ethiopia Sheep and Goat Productivity Improvement Program (ESGPIP), 5-26.

6. Beltrame, M. A. V., Pena, H. F. J., Ton, N. C., Lino, A. J. B., Gennari, S. M., Dubey, J. P., \& Pereira, F. E. L. (2012). Seroprevalence and isolation of Toxoplasma gondii from free-range chickens from Espírito Santo state, southeastern Brazil. Veterinary Parasitology, 188(3-4), 225-230. 
7. Berhanu, T., (2015). Seroepidemiology of Toxoplasmosis in Domestic Ruminants, Public Health Significance and Isolation of Toxoplasma gondii from Animal tissues in Selected Districts of East Hararghe Zone of Oromia Region, Ethiopia. p. 45-46.

8. Bourguin, I. S. A. B. E. L. L. E., Chardès, T. H. I. E. R. R. Y., \& Bout, D. (1993). Oral immunization with Toxoplasma gondii antigens in association with cholera toxin induces enhanced protective and cellmediated immunity in C57BL/6 mice. Infection and Immunity, 61(5), 2082-2088.

9. Brown, C. R., Hunter, C. A., Estes, R. G., Beckmann, E., Forman, J., David, C., ... McLeod, R. (1995). Definitive identification of a gene that confers resistance against Toxoplasma cyst burden and encephalitis. Immunology, 85(3), 419.

10. Cook, A. J. C., Holliman, R., Gilbert, R. E., Buffolano, W., Zufferey, J., Petersen, E., ... Dunn, D. T. (2000). Sources of toxoplasma infection in pregnant women: European multicentre case-control study Commentary: Congenital toxoplasmosis-further thought for food. BMJ, 321(7254), 142-147. https://doi.org/10.1136/bmj.321.7254.142

11. Cornelissen, J. B., van der Giessen, J. W., Takumi, K., Teunis, P. F., \& Wisselink, H. J. (2014). An experimental Toxoplasma gondii dose-response challenge model to study therapeutic or vaccine efficacy in cats. PloS one, 9(9), e104740. https://doi.org/10.1371/journal.pone.0104740

12. Dardé M. L. (2004). Genetic analysis of the diversity in Toxoplasma gondii. Annali dell'Istituto superiore di sanita, 4O(1), 57-63.

13. Deksne, G., \& Kirjušina, M. (2013). Seroprevalence of Toxoplasma gondii in domestic pigs (Sus scrofa domestica) and wild boars (Sus scrofa) in Latvia. The Journal of Parasitology, 99(1), 44-47. https://doi.org/10.1645/GE-3187.1

14. Dubey J. P. (2006). Comparative infectivity of oocysts and bradyzoites of Toxoplasma gondii for intermediate (mice) and definitive (cats) hosts. Veterinary parasitology, 140(1-2), 69-75. https://doi.org/10.1016/j.vetpar.2006.03.018.

15. Dubey, J. P. (1992). Isolation of Toxoplasma gondii from a naturally infected beef cow. The Journal of parasitology, 151-153.

16. Dubey, J. P. (1998). Refinement of pepsin digestion method for isolation of Toxoplasma gondii from infected tissues. Veterinary Parasitology, 74(1), 75-77.

17. Dubey, J. P. (2010). Toxoplasmosis of animals and humans. 2nd Ed. ed. 2010, Boca Raton Florida: U.S.A: CRC Press.

18. Dubey, J. P., Graham, D. H., Blackston, C. R., Lehmann, T., Gennari, S. M., Ragozo, A. M., Nishi, S. M., Shen, S. K., Kwok, O. C., Hill, D. E., \& Thulliez, P. (2002). Biological and genetic characterisation of Toxoplasma gondii isolates from chickens (Gallus domesticus) from São Paulo, Brazil: unexpected findings. International journal for parasitology, 32(1), 99-105. https://doi.org/10.1016/s00207519(01)00364-2

19. Dubey, J. P., Navarro, I. T., Sreekumar, C., Dahl, E., Freire, R. L., Kawabata, H. H., Vianna, M. C., Kwok, O. C., Shen, S. K., Thulliez, P., \& Lehmann, T. (2004a). Toxoplasma gondii infections in cats from Paraná, 
Brazil: seroprevalence, tissue distribution, and biologic and genetic characterization of isolates. The Journal of parasitology, 90(4), 721-726. https://doi.org/10.1645/GE-382R

20. Dubey, J. P., Rajendran, C., Ferreira, L. R., Martins, J., Kwok, O. C. H., Hill, D.E., ... Jones, J. L. (2011). High prevalence and genotypes of Toxoplasma gondii isolated from goats, from a retail meat store, destined for human consumption in the USA. International journal for parasitology, 41(8), 827-833. https://doi.org/10.1016/j.ijpara.2011.03.006

21. Dubey, J. P., Sundar, N., Gennari, S. M., Minervino, A. H. H., Farias, N. D. R., Ruas,J. L., ... Su, C. (2007b). Biologic and genetic comparison of Toxoplasma gondii isolates in free-range chickens from the northern Para state and the southern state Rio Grande do Sul, Brazil revealed highly diverse and distinct parasite populations. Veterinary parasitology, 143(2), 182-188.

22. Dubey, J. P., Weigel, R. M., Siegel, A. M., Thulliez, P., Kitron, U. D., Mitchell,M. A., ... Todd, K. S. (1995). Sources and reservoirs of Toxoplasma gondii infection on 47 swine farms in Illinois. The Journal of parasitology, 723-729. https://doi.org/10.2307/3283961

23. Dumètre, A., Ajzenberg, D., Rozette, L., Mercier, A., \& Dardé, M. L. (2006). Toxoplasma gondii infection in sheep from Haute-Vienne, France: seroprevalence and isolate genotyping by microsatellite analysis. Veterinary Parasitology, 142(3-4), 376-379. https://doi.org/10.1016/j.vetpar.2006.07.005

24. Elfadaly, H. A., Hassanan, N., Shaapan, R. M., Hassanain, M. A., Barakat, A. M., \& Abdelrahman, K. A. (2017). Molecular detection and genotyping of Toxoplasma gondii from Egyptian isolates. Asian J Epidemiol, 10, 37-44.

25. Esubalew, S., Tarekegn, Z., Jemberu, W. T., Nigatu, S. D., Kussa, M., Tsegaye, A. A., Asteraye, G. B., Bogale, B., \& Kebede, M. C., (2020). Seroepidemiology of Toxoplasma gondii in small ruminants in Northwest Ethiopia. Veterinary parasitology, regional studies and reports, 22, 100456. https://doi.org/10.1016/j.vprsr.2020.100456

26. Fritz, H., Barr, B., Packham, A., Melli, A., \& Conrad, P. A. (2012). Methods to produce and safely work with large numbers of Toxoplasma gondii oocysts and bradyzoite cysts. Journal of microbiological methods, 88(1), 47-52. https://doi.org/10.1016/j.mimet.2011.10.010

27. Garcia-Bocanegra, I., Cabezon, O., Hernandez, E., Martinez-Cruz, M. S., Martinez-Moreno, A., \& Martinez-Moreno, J. (2013). Toxoplasma gondii in ruminant species (cattle, sheep, and goats) from southern Spain. The Journal of parasitology, 99(3), 438-440. https://doi.org/10.1645/12-27.1

28. Gebremedhin, E. Z., Abdurahaman, M., Tessema, T. S., Tilahun, G., Cox, E., Goddeeris,B., ... Ajzenberg, D. (2014). Isolation and genotyping of viable Toxoplasma gondii from sheep and goats in Ethiopia destined for human consumption. Parasites \& Vectors, 7(1), 425. https://doi.org/10.1186/17563305-7-425

29. Gebremedhin, E. Z., Agonafir, A., Tessema, T. S., Tilahun, G., Medhin, G., Vitale, M., \& Di Marco, V. (2013). Some risk factors for reproductive failures and contribution of Toxoplasma gondii infection in sheep and goats of central Ethiopia: a cross-sectional study. Research in Veterinary Science, 95(3), 894-900. https://doi.org/10.1016/j.rvsc.2013.08.007 
30. Gebremedhin, E. Z., Kebeta, M. M., Asaye, M., Ashenafi, H., Marco, V. D., \& Vitale, M. (2015). Bioassay of Toxoplasma gondii from apparently healthy pigs slaughtered in Addis Ababa abattoir, Ethiopia. Journal of Veterinary Science and Technology, 6(5).

31. Gebremedhin, E.Z., Abdurahaman, M., Hadush, T. et al. Seroprevalence and risk factors of Toxoplasma gondii infection in sheep and goats slaughtered for human consumption in Central Ethiopia. BMC Res Notes 7, 696 (2014). https://doi.org/10.1186/1756-0500-7-696

32. Gharbi, M., Zribi, L., Jedidi, M., Chakkhari, H., Hamdi, S., R'hayem, S., ... Darghouth,M. A. (2013). Prevalence of Toxoplasma gondii infection in Tunisian sheep. Bulletin de la Societe de Pathologie Exotique (1990), 106(3), 184-187. DOI: 10.1007/s13149-013-0290-4

33. Goodwin, D. G., Strobl, J., Mitchell, S. M., Zajac, A. M., \& Lindsay, D. S. (2008). Evaluation of the mood-stabilizing agent valproic acid as a preventative for toxoplasmosis in mice and activity against tissue cysts in mice. Journal of Parasitology, 94(2), 555-557. https://doi.org/10.1645/GE-1331.1

34. Hosseini, S. A., Amouei, A., Sharif, M., Sarvi, S., Galal, L., Javidnia, J., Pagheh, A. S., Gholami, S., Mizani, A., \& Daryani, A. (2018). Human toxoplasmosis: a systematic review for genetic diversity of Toxoplasma gondii in clinical samples. Epidemiology and infection, 147, 1-9. Advance online publication. https://doi.org/10.1017/S0950268818002947

35. Jittapalapong, S., Sangvaranond, A., Pinyopanuwat, N., Chimnoi, W., Khachaeram, W., Koizumi, S., \& Maruyama, S. (2005). Seroprevalence of Toxoplasma gondii infection in domestic goats in Satun Province, Thailand. Veterinary Parasitology, 127(1), 17-22.

https://doi.org/10.1016/j.vetpar.2004.08.019

36. Kyan, H., Taira, M., Yamamoto, A., Inaba, C., \& Zakimi, S. (2012). Isolation and characterization of Toxoplasma gondii genotype from goats at an abattoir in Okinawa. Jpn. J. Infect. Dis, 65(2), 167170.

37. Lahmar, I., Lachkhem, A., Slama, D., Sakly, W., Haouas, N., Gorcii, M., ... Babba, H.(2015). Prevalence of toxoplasmosis in sheep, goats and cattle in Southern Tunisia.Journal of Bacteriology \& Parasitology, 6(5), 1. http://dx.doi.org/10.4172/2155-9597.1000245

38. Negash, T., Tilahun, G., Patton, S., Prevot, F., Dorchies, P.H. (2004). Serological survey on toxoplasmosis in sheep and goats in Nazareth, Ethiopia. Rev. Med. Vet. 155,486-488.

39. Opsteegh, M., Schares, G., Blaga, R., \& van der Giessen, J. (2016). Experimental studies on Toxoplasma gondii in the main livestock species (GP/EFSA/BIOHAZ/2013/01) Final report. EFSA Supporting Publications, 13(2), 995E. https://doi.org/10.2903/sp.efsa.2016.EN-995

40. Opsteegh, M., Teunis, P., Züchner, L., Koets, A., Langelaar, M., \& van der Giessen, J. (2011). Low predictive value of seroprevalence of Toxoplasma gondii in cattle for detection of parasite DNA. International Journal for Parasitology, 41(3-4), 343-354. https://doi.org/10.1016/j.ijpara.2010.10.006

41. Pena, H. F. J., Gennari, S. M., Dubey, J. P., \& Su, C. (2008). Population structure and mouse-virulence of Toxoplasma gondii in Brazil. International journal for parasitology, 38(5), 561-569. https://doi.org/10.1016/j.ijpara.2007.09.004 
42. Ragozo, A. M. A., Yai, L. E. O., Oliveira, L. N., Dias, R. A., Dubey, J. P., \& Gennari, S. M. (2008). Seroprevalence and isolation of Toxoplasma gondii from sheep from Sao Paulo State, Brazil. Journal of Parasitology, 94(6), 1259-1263. https://doi.org/10.1645/GE-1641.1

43. Ragozo, A. M. A., Yai, L. E. O., Oliveira, L. N., Dias, R. A., Goncalves, H. C., Azevedo,S. S., ... Gennari, S. M. (2009). Isolation of Toxoplasma gondii from goats from Brazil. Journal of Parasitology, 95(2), 323-326. https://doi.org/10.1645/GE-1854.1

44. Ramzan, M., Akhtar, M., Muhammad, F., Hussain, I., Hiszczyńska-Sawicka, E., Haq, A.U., ... Hafeez, M. A. (2009). Seroprevalence of Toxoplasma gondii in sheep and goats in Rahim Yar Khan (Punjab),
Pakistan. Tropical animal health and production, 41(7), 1225. https://doi.org/10.1007/s11250-009-
$9304-0$

45. Robert-Gangneux, F., Darde, M.L. (2012). Epidemiology of and diagnostic strategies for toxoplasmosis. Clin. Microbial. Rev. 25 (2), 264-296. https://doi.org/10.1128/CMR.05013-11.

46. Rong, G., Zhou, H.L., Hou, G.Y., Zhao, J.M., Xu, T.S., Guan, S. (2014). Seroprevalence, risk factors and genotyping of Toxoplasma gondii in domestic geese (Anser domestica) in tropical China. Parasit. Vectors 7, 459. https://doi.org/10.1186/s13071-014-0459-9

47. Saadatnia, G., \& Golkar, M. (2012). A review on human toxoplasmosis. Scandinavian journal of infectious diseases, 44(11), 805-814. https://doi.org/10.3109/00365548.2012.693197.

48. Scarpelli, L., Lopes, W. D. Z., Migani, M., Bresciani, K. D. S., \& Costa, A. J. D. (2009). Toxoplasma gondii in experimentally infected Bos taurus and Bos indicus semen and tissues. Pesquisa Veterinária Brasileira, 29(1), 59-64.

49. Schlüter, D., Däubener, W., Schares, G., Groß, U., Pleyer, U., \& Lüder, C. (2014). Animals are key to human toxoplasmosis. International journal of medical microbiology: IJMM, 304(7), 917-929. https://doi.org/10.1016/j.ijmm.2014.09.002

50. Shapiro, K., Bahia-Oliveira, L., Dixon, B., Dumètre, A., de Wit, L. A., VanWormer, E., \& Villena, I. (2019). Environmental transmission of Toxoplasma gondii: Oocysts in water, soil and food. Food and waterborne parasitology, 15, e00049. https://doi.org/10.1016/j.fawpar.2019.e00049.

51. Stelzer, S., Basso, W., Benavides Silván, J., Ortega-Mora, L. M., Maksimov, P., Gethmann, J., Conraths, F. J., \& Schares, G. (2019). Toxoplasma gondii infection and toxoplasmosis in farm animals: Risk factors and economic impact. Food and waterborne parasitology, 15, e00037. https://doi.org/10.1016/j.fawpar.2019.e00037

52. Taylor, R. E. (1984). Beef production and the beef industry: a beef producer's perspective. Burgess Publishing Company.

53. Tegegne, D., Kelifa, A., Abdurahaman, M., Yohannes, M. (2016). Seroepidemiology and associated risk factors of Toxoplasma gondii in sheep and goats in Southwestern Ethiopia. BMC Veterinary Research, 12 (1), 280. https://doi.org/10.1186/s12917-016-0906-2.

54. Tenter A. M. (2009). Toxoplasma gondii in animals used for human consumption. Memorias do Instituto Oswaldo Cruz, 104(2), 364-369. https://doi.org/10.1590/s0074-02762009000200033 
55. Tesfamariam, G., (2013). Seroepidemiology and isolation of Toxoplasma gondii from free-range chicken of central Ethiopia. MSc thesis. Addis Ababa University College of Veterinary Medicine and Agriculture, Bishoftu. p. Pp. 41.

56. Teshale, S., Dumetre, A., Dardé, M. L., Merga, B., \& Dorchies, P. (2007). Serological survey of caprine toxoplasmosis in Ethiopia: prevalence and risk factors. Parasite, 14(2), 155-159. https://dx.doi.org/10.1051/parasite/2007142155

57. Tilahun, B., Tolossa, Y. H., Tilahun, G., Ashenafi, H., \& Shimelis, S. (2018). Seroprevalence and Risk Factors of Toxoplasma gondii Infection among Domestic Ruminants in East Hararghe Zone of Oromia Region, Ethiopia. Veterinary medicine international, 2018, 4263470. https://doi.org/10.1155/2018/4263470

58. Tonouhewa, A. B., Akpo, Y., Sessou, P., Adoligbe, C., Yessinou, E., Hounmanou, Y. G., Assogba, M. N., Youssao, I., \& Farougou, S. (2017). Toxoplasma gondii infection in meat animals from Africa: Systematic review and meta-analysis of seroepidemiological studies. Veterinary World, 10(2), 194208. https://doi.org/10.14202/vetworld.2017.194-208

59. Wang, L., Cheng, H. W., Huang, K. Q., Xu, Y. H., Li, Y. N., Du, J., ... Shen, J. L.(2013). Toxoplasma gondii prevalence in food animals and rodents in different regions of China: isolation,genotyping and mouse pathogenicity. Parasites \& Vectors, 6(1), 273. https://doi.org/10.1186/1756-3305-6-273

60. Waree, P., Ferguson, D. J., Pongponratn, E., Chaisri, U., \& Sukthana, Y. (2007). Immunohistochemical study of acute and chronic toxoplasmosis in experimentally infected mice. Southeast Asian journal of tropical medicine and public health, 38(2), 223.

61. Yang, N., Mu, M.Y., Li, H.K., Long, M., He, J.B. (2012). Seroprevalence of Toxoplasma gondii infection in slaughtered chickens, ducks, and geese in Shenyang, North-Eastern China. Parasit. Vectors 5, 237. https://doi.org/10.1186/1756-3305-5-237.

62. Yibeltal, M. M. (2008). Seroprevalence study of toxoplasmosis in small ruminants and humans (HIV/AIDS patient) in the selected district of South Wollo, Ethiopia. Debre-Zeit: Addis Ababa University, Faculty of Veterinary Medicine, 25-40.

63. Yildiz, K., KUL, O., GÖKPINAR, S., Atmaca, H. T., Gencay, Y. E., GAZYAĞCl, A. N.,... GÜRCAN, İ. S. (2014). The relationship between seropositivity and tissue cysts in sheep naturally infected with Toxoplasma gondii. Turkish Journal of Veterinary and Animal Sciences, 38(2), 169-175.

64. Younis, E. E., Abou-Zeid, N. Z., Zakaria, M., \& Mahmoud, M. R. (2015). Epidemiological studies on toxoplasmosis in small ruminants and equine in Dakahlia governorate, Egypt. Assiut Vet. Med. J, 61(145), 22-31.

65. Zewdu, E., Agonafir, A., Tessema, T.S., Tilahun, G., Medhin, G., Vitale, M., Di Marco, V., Cox, E., Vercruysse, J., Dorny, P. (2013). Seroepidemiological study of caprine toxoplasmosis in east and west Shewa zones, Oromia regional state, Central Ethiopia. Research in Veterinary Sciences 94 (1), 43-48. https://doi.org/10.1016/j.rvsc.2012.07.020.

\section{Tables}


Table 1

\begin{tabular}{|c|c|c|c|c|c|c|}
\hline \multicolumn{2}{|c|}{ Risk factors } & \multirow{2}{*}{$\begin{array}{l}\text { Category } \\
\text { Female }\end{array}$} & \multirow{2}{*}{$\begin{array}{l}\text { No. of samples } \\
49\end{array}$} & \multirow{2}{*}{$\begin{array}{l}\text { No. infected (\%) } \\
31(63.3)\end{array}$} & \multirow{2}{*}{$\begin{array}{l}\chi^{2} \\
4.55\end{array}$} & \multirow{2}{*}{$\begin{array}{l}P \text {-value } \\
0.033\end{array}$} \\
\hline & & & & & & \\
\hline & Sex & Male & 86 & $38(44.2)$ & & \\
\hline \multirow[t]{4}{*}{ Sheep } & & Adult & 102 & $59(57.8)$ & 7.57 & 0.006 \\
\hline & Age & Young & 33 & $10(30.3)$ & & \\
\hline & & Old & 22 & 19 (86.36) & 7.81 & 0.005 \\
\hline & Age & Adult & 128 & $70(50.5)$ & & \\
\hline \multirow[t]{2}{*}{ Cattle } & & Cross & 20 & $17(85.0)$ & 6.3 & 0.012 \\
\hline & Breed & Local & 130 & 72 (55.38) & & \\
\hline \multirow[t]{4}{*}{ Goats } & Sex & Female & 21 & $12(57.1)$ & 0.01 & 0.92 \\
\hline & & Male & 29 & 17(58.6) & & \\
\hline & Age & Young & 11 & $5(45.5)$ & 1.6 & 0.21 \\
\hline & & Adult & 39 & $24(61.5)$ & & \\
\hline
\end{tabular}

Table 2

Source No. of isolates

Species inoculated into mice.

Sheep 16

Cattle $\quad 14$

Goat 9

Total $\quad 39$
Seropositive in mice $(\%)[95 \% \mathrm{Cl}]$

7(43.8) [18.868.8] $3(21.4)[0.2-42.9] \quad 2(14.3)[0.0-35.7] \quad 3(21.4)[0.2-42.9]$ $4(44.4)[11.1-$ 77.8]

14(35.9) [20.551.3]
Cyst positive in The overall positive in mice $(\%)[95 \% \mathrm{Cl}] \quad$ mice $(\%)[95 \% \mathrm{Cl}]$

$8(25)[25-75]$

7(43.8) [18.868.8]

$3(33.3)[0.00-\quad 4(44.4)[11.1-77.8]$ 66.7]

$12(30.8)[17.9-\quad 15(38.5)$ [23.1-53.8] 46.2]

Table 3 
Species ID Seropositive/examined mice
Cyst positive/examined mice
Mice dead/No. inoculated mice

Sheep

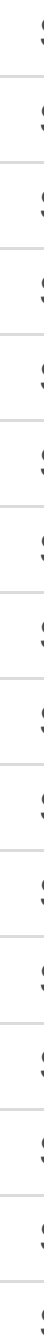

Sp13

Sp1

Sp1

Sp25 2/4

Sp26 2/3

Sp28 3/4

Sp35 0/5

Sp43 0/5

Sp49 $\quad 0 / 4$

Sp51 0/5

Sp55 3/5

Sp62 0/5

Sp63 0/5

Sp66 0/5

Sp67 0/5

Cattle

$\begin{array}{ll}\text { B10 } & 0 / 5 \\ \text { B14 } & 3 / 3\end{array}$

B17 0/4

B21 0/4

B28 0/5

B35 0/5

B36 0/5

B40 0/5

B48 2/4

B52 $\quad 0 / 5$

B54 $\quad 0 / 5$
$0 / 3 \quad 1 / 4$

$2 / 4$

$2 / 5$

$2 / 4$

$1 / 4$

$2 / 3$

$0 / 4$

$0 / 5$

$0 / 5$

$2 / 4$

$0 / 5$

$3 / 5$

$0 / 5$

$0 / 5$

$0 / 5$

$0 / 5$

$0 / 5$

$1 / 3$

$0 / 4$

$0 / 4$

$0 / 5$

$0 / 5$

$0 / 5$

$0 / 5$

$0 / 4$

$0 / 5$

$0 / 5$

Page 16/19
Days of mice death PI (No. of mice)

13(1)

8(1)

All survived

9(1)

21(1)

16(1), 23(1)

$30(1)$

All survived

All survived

30(1)

All survived

All survived

All survived

All survived

All survived

3(3), 4(2)

All survived

$34(1), 36(1)$

26(1)

35(1)

All survived

All survived

All survived

All survived

40(1)

All survived

All survived 


\begin{tabular}{clllll}
\hline & B62 & $0 / 5$ & $0 / 5$ & $0 / 5$ & All survived \\
\hline & B65 & $3 / 3$ & $1 / 3$ & $2 / 5$ & $8(1), 9(1)$ \\
\hline Goat & B66 & $0 / 5$ & $0 / 5$ & $0 / 5$ & All survived \\
\hline & Gt2 & $2 / 5$ & $2 / 5$ & $0 / 5$ & All survived \\
\hline & Gt4 & $2 / 4$ & $0 / 4$ & $0 / 5$ & $30(1)$ \\
\hline Gt6 & $1 / 1$ & $1 / 1$ & $4 / 5$ & $3(2), 4(2)$ \\
\hline Gt8 & $0 / 5$ & $0 / 5$ & $0 / 5$ & All survived \\
\hline Gt25 & $0 / 5$ & $0 / 5$ & $0 / 5$ & All survived \\
\hline Gt28 & $1 / 3$ & $2 / 3$ & $2 / 5$ & $17(1), 28(1)$ \\
\hline Gt33 & $0 / 4$ & $0 / 4$ & $1 / 5$ & $16(1)$ \\
\hline Gt46 & $0 / 4$ & $0 / 4$ & $1 / 5$ & $25(1)$ \\
\hline Gt48 & $0 / 5$ & $0 / 5$ & $0 / 5$ & All survived
\end{tabular}

Table 4

Sample Bio-assayed samples per Sources group mice

\section{Seropositive Cyst positive}

(n)

(n) $\begin{array}{llll}\begin{array}{l}\text { No. cyst-positive } \\ \text { mice }\end{array} & \begin{array}{l}\text { Mean } \\ \text { cyst }\end{array} & \text { SE } & \text { Range }\end{array}$

count

$\begin{array}{lcccccc}\begin{array}{l}\text { Sheep } \\ (\mathrm{n}=16)\end{array} & 7 & 7 & 14 & 129.57 & 36.597 & 36- \\ 550\end{array}$

$\mathrm{SE}=$ standard error

Figures 


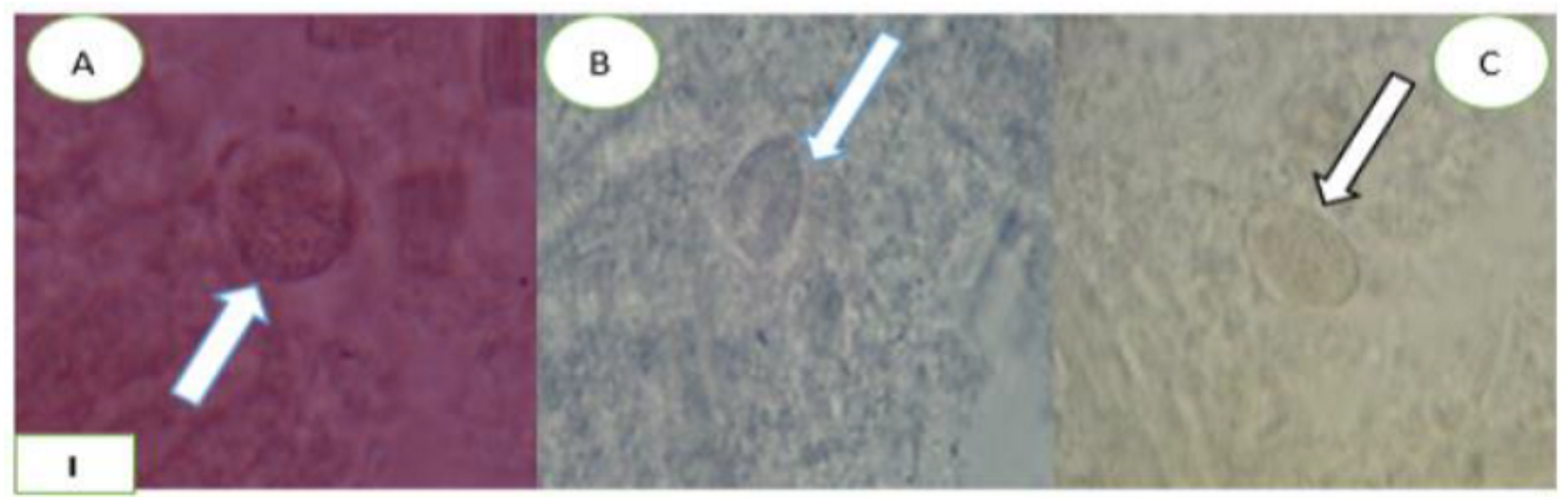

T. gondii tissue cysts from pepsin digested animal heart tissue sample: $\mathbf{A}=$ from cattle; $\mathbf{B}=$ from goat; $\mathbf{C}=$ from sheep. Note the thin cyst wall (arrow) enclosing
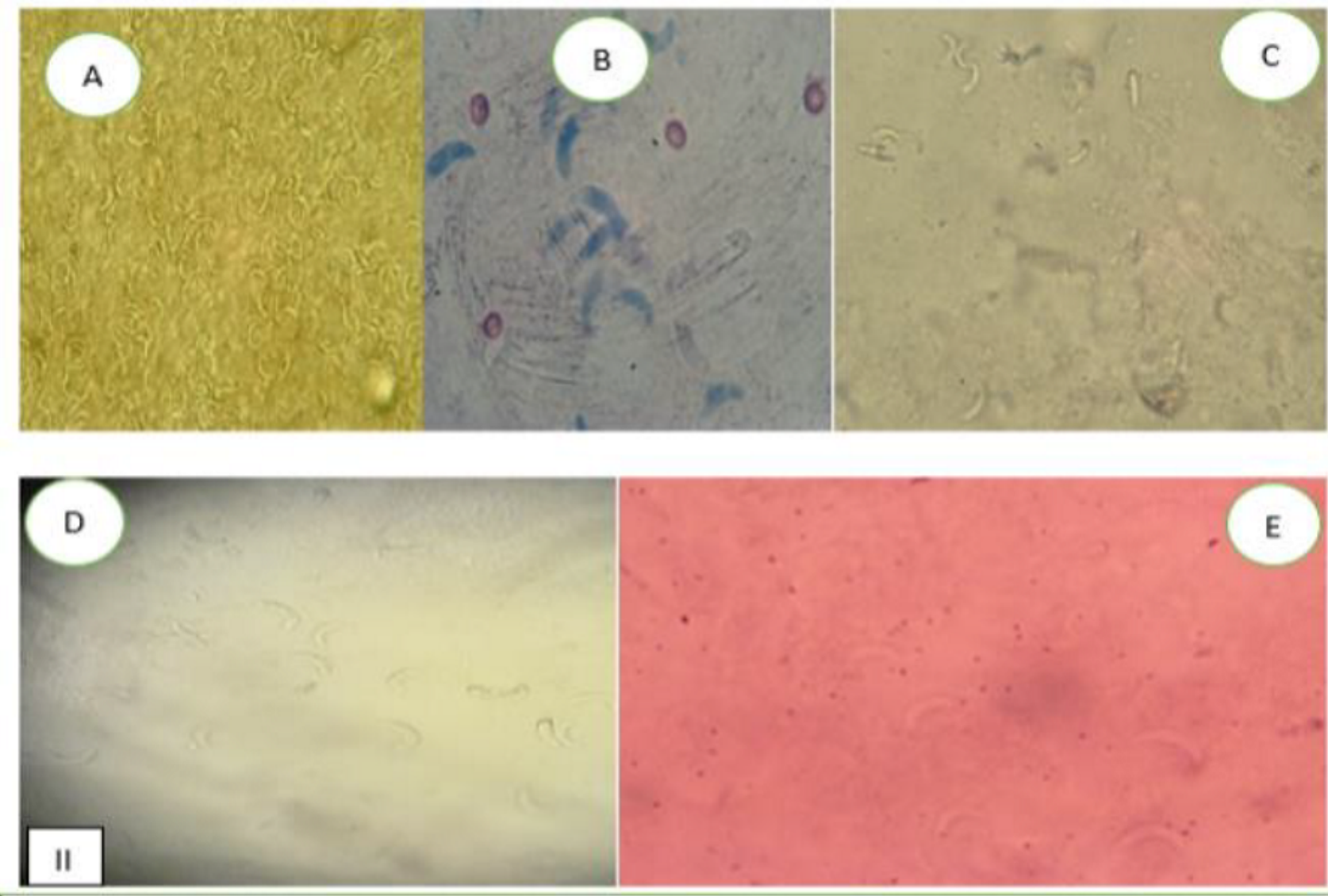

Microscopically detected liberated bradyzoites of $T$. gondii: $\mathrm{A}=$ from cattle, $\mathrm{B}=$ Giemsa stained from cattle; $C=$ from goat; $D$ and $E=$ from sheep

\section{Figure 1}

T. gondii tissue cysts (I) and liberated bradyzoites (II). 

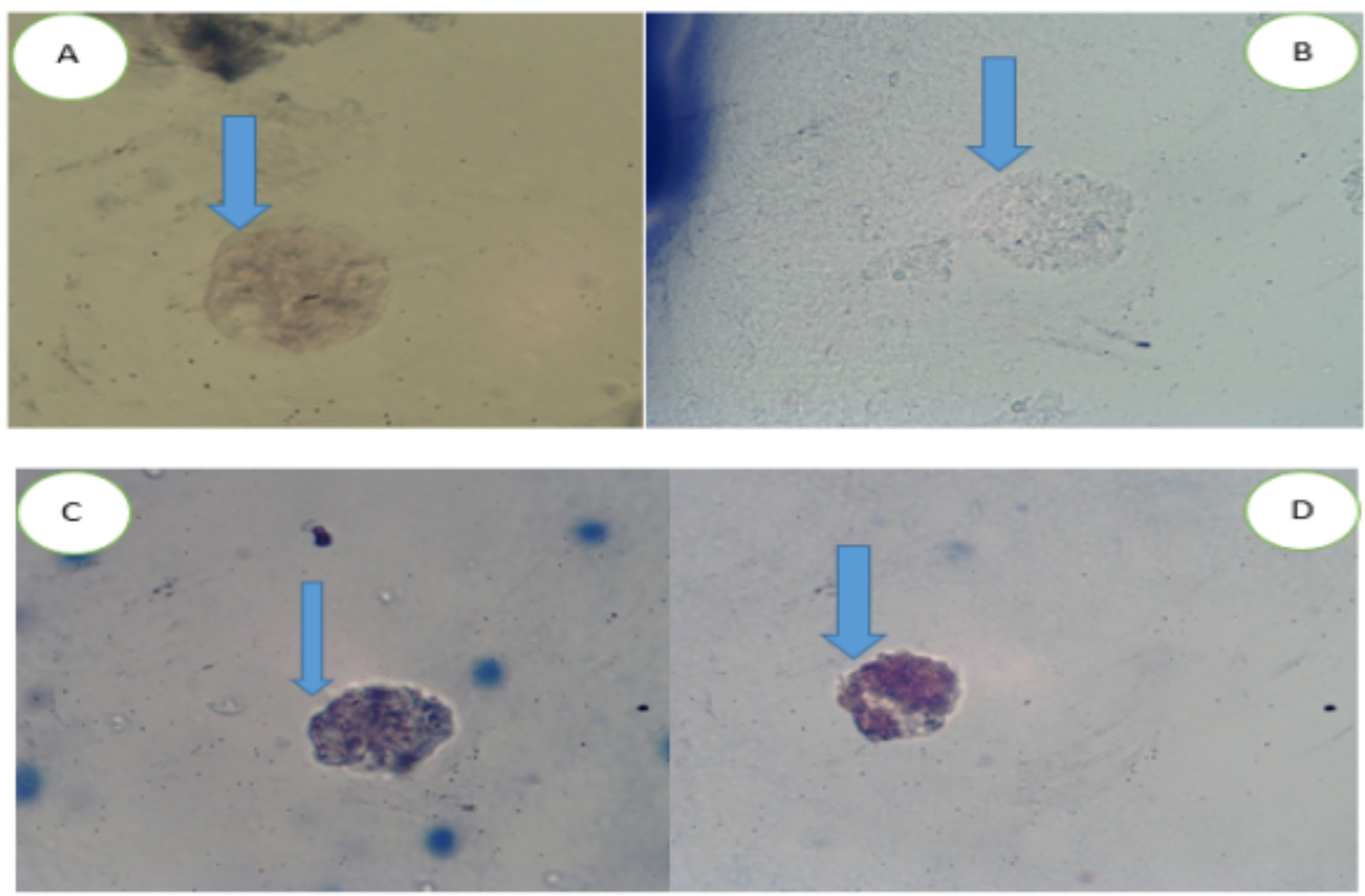

\section{Figure 2}

Tissue cysts of $T$. gondii isolated from the brain of mice: from sheep sample inoculum [ $A=$ unstained 40x], goat sample inoculum [B= unstained; $C=$ impression smear $100 x]$, and cattle [ $D$ impression $100 x$ smear]. Note the thin cyst wall (arrow) enclosing bradyzoites. 